\title{
Concessionary Model of the Real Investment Process Financing Based on the Financial Engineering Tools
}

\section{Elena Gennadiievna Knyazeva}

Department of Insurance Ural Federal University named after the first President of Russia B.N. Yeltsin, Russia, Ekaterinburg, 620002, Ekaterinburg, 19 Mira, Str.

\section{Tatyana Mikhailovna Kovaleva}

Department of finances and credit Samara State University of Economics, Samara, Russia, 443090, Samara, 141 Sovetskoy Armii Str.

\section{Larisa Ivanovna Yuzvovich}

Department of Insurance Ural Federal University named after the first President of Russia B.N. Yeltsin, Russia, Ekaterinburg, 620002, Ekaterinburg, 19 Mira, Str..

\author{
Alexey Valeriievich Orlov \\ First Deputy Chairman of the government of Sverdlovsk region, Ekaterinburg, Russia, 620031, \\ Ekaterinburg, 1 Oktyabrya Sq. \\ Nadiya Mikhailovna Sabitova \\ Department of Finance of the Kazan (Volga region) Federal University, 420008, Russia, \\ Republic of Tatarstan, Kazan, 18 Kremliovskaya Str.
}

Doi:10.5901/mjss.2015.v6n3s3p399

\section{Abstract}

Nowadays a considerable attention is paid to the issues of public and private partnership within development of investment projects and to possible prospects of development of state-private interaction forms in the investment sphere, in particular, concessions. The enhancement of interaction forms of the state with the corporate sector of economy in the field of real investments implementation and within development of investing programs of a certain priority requiring considerable investments has a strategic value, both federal and regional. Thus, it is important to understand the role and the benefit of each participant of the investment market, to determine the accurate standard, legislative, and contractual basis, to analyse quickly the financial performance of real investments at all the stages of implementation. The experience of many countries of the world with various economic systems and models, the development level of the market relations, witnesses that one of the most effective ways of providing quantity and quality characteristics of state-owned property objects is attraction of a private capital to financing and management. However, it shall be done not on the ways of their privatisation, but on a concessionary basis. One of the most important and perspective directions of economic policy of the state in the field of management of the objects in their property, is the solution of an investment problem in general and the budget problem in particular, is a broad application of concessionary agreements and projects, because concessions are an option of preserving the state-owned property.

Keywords: concessions, concessionary models, types of concessionary agreements, investment process, financial engineering.

\section{Introduction}

\subsection{Introduce the Problem}

In the reality of difficult and large-scale modern economy, the combination of the market mechanisms and the state regulation instruments into a single system is vital. 
Nowadays in the majority of the countries of the world, the development of national economy is characterised by search of new forms and methods of public administration and regulation, by considerable structural shifts in the direction of economy liberalisation. The happening changes are in a segment of conservative policy and they mean weakening of direct and indirect state regulation, strengthening of a role and value of private investors in strategic industries of national economy, establishment of partnership between the state and business. The increase of the private sector value reflects the target concept of the state in development of industry complexes, infrastructure, and separate segments of management.

\subsection{Importance of the Problem}

In Russia, the law "On Concessionary Agreements" was adopted in 2005. The purposes of this federal law are investment attraction in the economy of Russian Federation, ensuring effective use of the property of the state-owned or municipal property on the terms of concessionary agreements and improvement of quality of goods, works, the services provided to consumers.

The practical importance of the research is determined by the possibility of direct use of results and developed recommendations for the purpose of practical tasks solutions by enhancement of concessionary mechanisms.

Different concession models in the contracts system are between privatisation and functioning of the state entity. They differ from lease in separation of risks, participation of the state, transfer of some state functions. Considering these parameters, it is possible to find a compliance between various models of concessionary contracts.

Concessions have gained a considerable development in Europe (programs of private financing of infrastructures in England, Holland, Portugal and Spain) and in other countries of the world, in particular, in Japan.

\subsection{Relevant Scholarship}

Financing of real investments and problem of institutional transformations of investing activities are provided in works of the leading representatives of scientific thought: V. D. Andrianova, G. Birman, Y. V. Bogatin, D. A. Endovitsky, N. V. Igoshin, A. Y. Cossack, N. Kravchenko, M. S. Maramygin, P. Masse, Y. M. Mirkin, V. S. Pashkovsky, J. Saks, A. Smith, S. K. Semenov, V. E. Cherkasova, E. M. Chetyrkin, S. Schmidt, and V. A. Shvan-dar. Conceptual reasons for financial tools of investment attraction to the Russian economy as concessions, joint businesses, special economic zones as effective methods of real investments financing contain in works of domestic economists: E. F. Avdokushin, Y. Z. Andrianov, Y. L. Bondarenko, N. T. Krasnolutskaya, N. A.Orlov, S. A. Rybakov, I. V. Rykova, and E. D. Halevinskaya.

\subsection{State Hypotheses and Their Correspondence to Research Design}

The task of perspective development of concessionary activities was set for a group of authors in the Russian Federation in the field of its financing, taking into account its both economic and industry features. It is about tax transformations in the areas of concessionary activities, because for an effective financing by involvement of the private investor in various types of concessions from the state there shall be certain incentives.

In the scientific article, the concessionary model of real investment process financing with submission of the schematic diagram of implementation and economic determinacy of conditions within enhancement of financing system of real investments is offered. The scientific line item, considering forming of general and private elements of tax privileges using tools of financial engineering, is proved. The differentiation of tax privileges general elements, caused by interrelation of rational conditions of legal support and taxation and interests of the concessionary transaction participants, is established.

\section{Methods}

\subsection{Method of statistical monitoring}

In the work, analytical data of the Investment fund of the Russian Federation, within implementation of real investment projects of the federal and regional level, have been used. The information base is quite representative, that's why there is a reliable basis for creation of a complete picture of a complex analysis technique of investment projects based on analytical materials of scientific and practical conferences; expert data of periodicals; reference materials and electronic information systems. 


\subsection{Method of analysis and measurement}

In our opinion, change of rules for apportionment of profit during the creation of a concessionary agreement, and then tax privileges in the course of construction, management, ownership and transfer of concessionary object can become one of forms of support of public-private partnership regarding effective functioning of concessionary mechanisms, and thus, creation of a particular tax regime for concessionary activities.

The particular tax regime shall balance a concessionary payment and tax payments in a way that it could provide the investors with market operating conditions, having resolved at the same time the legal issues.

As possible types of the state support, as a rule, is considered the following ones:

- Provision of state guarantees or national insurance;

- Provision of subsidies;

- Crediting, participation in assets or ensuring the additional (integrated) investments;

- Changes in the taxation system.

Speaking about the legal features of tax nature, which for concessions generate problems with the general tax regime, we can name the following:

- The value added tax (VAT) - there can be contradictions in case of transferring of obligations of regional authorities on implementation of services to the population to the concessionary. The VAT is not levied from the authorities, however, it will be levied from the concessionary, which worsens his line item and raises the price of services for the consumer. The authorities can use the VAT compensation (in a case when the private sector makes out the bills including VAT directly to authorities).

- The income tax of the organisations - a deduction of costs for the request from taxable profit (regardless of that, it was or was not successful).

- Possibility for the participants of consortium after concessionary contract performance to apply the rules for the taxation of financial and industrial groups profits (to cover the losses from one projects at the expense of profit on others).

- In case of existence of several rates for the income tax (for example, for production and intermediary operations), it is necessary to determine the profit rate for the concessionary; it is necessary to consider possibility of application of individual rates also.

- Expansion of the investment tax privilege coverage for infrastructure projects, as the investments into machines and the equipment usually get under it.

- For provision of some deductions on investments in real estate the principle of essential interest ("relevant interest") which is recognised to that in case of long-term lease or ownership property, is used. However, if the company simply occupies the building, it can become a cause of failure in the tax deduction.

\subsection{Taxonomic method}

Based on the problems formulated above, the following questions can arise:

- Whether the profit of the concessionary shall belong completely to the year of origin, or it can be correlated to all the project term?

- How the income from use of state real estate will be considered - as profit of the concessionary or how taxfree receipts from transactions with capital assets? It is possible to consider four methods of entering of "excessive" real estate in the contract:

1) The cost of "excessively" transferred property it is considered as payment for future services;

2) The concessionary determines previously, what objects "are excessive" for his needs, in the contract they are transferred to the order of the construction organisation, and the income from use is transferred to the operator;

3) The cost of the land is considered as payment to the operator for the expense reduction;

4) The income from use of the land is considered as a payment to the operator to reduce the capital cost of the project.

- In case of creation of a special company for the project objectives, the fee in the form of real estate or equipment shall not be taxed.

In the conditions of national economy upgrade, the need of entering of a special tax regime consists in legal and infrastructure features. The condition of industries and objects of real sector of the Russian economy requires radical upgrade, reconstruction and updating, which is impossible without a broad attraction of a private capital. For example, the 
current situation in a road industry of Russia is characterised by the following indicators:

- The annual amount of economic losses from a bad state of the highways is estimated more than at $3 \%$ of GDP;

- Only $8 \%$ of roads of federal value have the multiband carriageway;

- Only $37 \%$ of federal and $41 \%$ of regional and inter-municipal roads conform to standard requirements;

- Russia population mobility is nearly 2.5 times lower than in the developed foreign countries;

- due to the lack of roads with a hard surface, more than $10 \%$ of the population during the spring and autumn periods remain cut off from transport communications.

First, because of the legal features of the concessionary mechanism caused by the fact that the property belongs to the concessor (state), it is necessary to settle rather significant questions:

1) To determine, who will pay the property tax;

2) As the property upon the concession termination returns to the state, it can be interested in the taxes accumulation by the concessionary, and that the taxes were put in development of property; taxes are accumulates and at the end are transferred to the state in the form of property;

3) It is also necessary to resolve the problem of a depreciation order etc.

It is necessary to find a balance between stability and flexibility, because the countries are interested in "binding their hands" to attract the investor. Thus, it is necessary to consider that the flexibility also has its costs. Non-standard forms of support, including non-standard guarantees, can lift the negotiations costs and increase transactional expenses. Therefore, simple decisions are frequently more preferable than the "ideal" separation of risk.

\subsection{Method of observational generalisation and logical inference}

The authors have made the analysis of the main types of concessions from the point of view of the concessionary activities taxation (tab. 1-4). During development of concessionary model of transformation and rationalisation of the financial and credit mechanism of attraction of real investments in the conditions of upgrade and adjustment of the taxation, standard legal acts in the field of the taxation of special economic zones, the simplified taxation system, regional regulations applied to special tax regimes were used.

Table 1. The concessionary model Build, Operate and Transfer (HERE) - projects within public-private partnership

\begin{tabular}{|c|c|c|}
\hline \multirow[b]{2}{*}{ The existing tax preferences } & \multicolumn{2}{|c|}{ Offered tax privileges } \\
\hline & General elements of the tax privilege & $\begin{array}{l}\text { Private elements } \\
\text { of the tax privilege }\end{array}$ \\
\hline $\begin{array}{l}\text { 1. VAT: the tax deduction is provided to the } \\
\text { concessionary (gl.21 Art. } 174.1 \text { of the Tax Code } \\
\text { of the Russian Federation) }\end{array}$ & $\begin{array}{l}\text { VAT: construction }-0 \% \text {; } \\
\text { management }-4,5 \%\end{array}$ & Free provision of the state lands \\
\hline $\begin{array}{l}\text { 2. Income tax: it isn't considered in case of } \\
\text { determination of a tax base (the cost of } \\
\text { depreciable property and a payment brought by } \\
\text { the concessionary to the concessor during } \\
\text { operation of object of the concessionary } \\
\text { agreement) }\end{array}$ & $\begin{array}{c}\text { The income tax - } 15,5 \% \text {, including } \\
2 \% \text { - the federal budget, } \\
13,5 \% \text { - the regional budget }\end{array}$ & $\begin{array}{c}\text { The tax holidays in the process of transferring } \\
\text { of the concessionary object }\end{array}$ \\
\hline \multirow{3}{*}{$\begin{array}{l}\text { 3. Property tax: the parcels of land, objects of } \\
\text { environmental management and other natural } \\
\text { resources aren't recognised the taxation objects; } \\
\text { the property belonging to military services, civil } \\
\text { defence and protection of a law and order }\end{array}$} & $\begin{array}{l}\text { Property tax of the organisations, } \\
\qquad \text { vehicle tax, } \\
\text { the land tax }-0 \% \text { within } 5 \text { years } \\
\text { from the moment of registration }\end{array}$ & Partial or full relief from customs duties \\
\hline & $\begin{array}{l}\text { Investment privilege: reduction of } \\
\text { taxable basis by } 10 \%\end{array}$ & $\begin{array}{l}\text { Enhancement of depreciation policy for the } \\
\text { purpose of the capital assets updating }\end{array}$ \\
\hline & & $\begin{array}{l}\text { Investment tax credit } \\
\text { for } 5 \text { years }\end{array}$ \\
\hline
\end{tabular}


Table 2. The concessionary model Build, Own, Operate, and Transfer (BOOT) - projects within public-private partnership

\begin{tabular}{|c|c|c|}
\hline \multirow{2}{*}{ The existing tax preferences } & \multicolumn{2}{|c|}{ Offered tax privileges } \\
\hline & General elements of the tax privilege & Private elements of the tax privilege \\
\hline $\begin{array}{l}\text { 1. VAT: the tax deduction is provided to the } \\
\text { concessionary (gl.21 Art. 174.1 of the Tax Code of } \\
\text { the Russian Federation) }\end{array}$ & $\begin{array}{l}\text { VAT: construction }-0 \% \text {, } \\
\text { management }-4,5 \% \\
\text { ownership - } 18 \%\end{array}$ & Free provision of the state lands \\
\hline $\begin{array}{l}\text { 2. Income tax: it isn't considered in case of } \\
\text { determination of a tax base (the cost of depreciable } \\
\text { property and a payment brought by the } \\
\text { concessionary to the concessor during operation of } \\
\text { object of the concessionary agreement) }\end{array}$ & $\begin{array}{l}\text { The income tax }-15,5 \%, \\
\text { including } \\
\text { 2\% - the federal budget, } \\
13,5 \% \text { - the regional budget }\end{array}$ & $\begin{array}{c}\text { Partial or full relief from customs duties } \\
\text { The tax holidays in process of the transferring } \\
\text { of the concessionary object }\end{array}$ \\
\hline \multirow[t]{2}{*}{$\begin{array}{l}\text { 3. Property tax: the parcels of land, objects of } \\
\text { environmental management and other natural } \\
\text { resources aren't recognised the taxation objects; the } \\
\text { property belonging to military services, services of } \\
\text { civil defence and protection of a law and order }\end{array}$} & $\begin{array}{c}\text { Regional and local taxes: } \\
\text { The property tax of the organisations } \\
-0 \%, \\
\text { vehicle tax }-0 \%, \\
\text { the land tax }-0 \% \\
\text { within } 5 \text { years from the moment of } \\
\text { registration }\end{array}$ & $\begin{array}{c}\text { Enhancement of the depreciation policy for the } \\
\text { purpose of the capital assets updating }\end{array}$ \\
\hline & $\begin{array}{l}\text { Investment privilege: reduction of } \\
\text { taxable basis by } 10 \%\end{array}$ & The investment tax credit for 5 years \\
\hline
\end{tabular}

Table 3. The concessionary model Build, Own and Operate, (BOO) - projects within public-private partnership

\begin{tabular}{|c|c|c|}
\hline \multirow[t]{2}{*}{ The existing tax preferences } & \multicolumn{2}{|c|}{ Offered tax privileges } \\
\hline & Private elements of the tax privilege & Private elements of the tax privilege \\
\hline $\begin{array}{l}\text { 1. VAT: the tax deduction is provided to the } \\
\text { concessionary (gl.21 Art. } 174.1 \text { of the Tax Code } \\
\text { of the Russian Federation) }\end{array}$ & $\begin{array}{c}\text { VAT: construction }-0 \% \text {, } \\
\text { management }-4,5 \% \\
\text { ownership }-18 \% \\
\end{array}$ & $\begin{array}{l}\text { Partial or complete } \\
\text { release from customs duties }\end{array}$ \\
\hline $\begin{array}{l}\text { 2. Income tax: it isn't considered in case of } \\
\text { determination of a tax base (the cost of } \\
\text { depreciable property and a payment brought by } \\
\text { the concessionary to the concessor during } \\
\text { operation of object of the concessionary } \\
\text { agreement) }\end{array}$ & $\begin{array}{l}\text { The income tax }-15,5 \%, \\
\text { including } \\
2 \% \text { - the federal budget, } \\
13,5 \% \text { - the regional budget }\end{array}$ & The investment tax credit for 5 years \\
\hline $\begin{array}{l}\text { 3. Property tax: the parcels of land, objects of } \\
\text { environmental management and other natural } \\
\text { resources aren't recognised the taxation objects; } \\
\text { the property belonging to military services, civil } \\
\text { defence and protection of law and order }\end{array}$ & $\begin{array}{c}\text { Regional and local taxes: } \\
\text { The property tax of the organisations - } \\
0 \% \\
\text { vehicle tax }-0 \% \\
\text { the land tax }-0 \% \\
\text { within } 5 \text { years from the moment of } \\
\text { registration }\end{array}$ & $\begin{array}{l}\text { Enhancement of depreciation policy for the } \\
\text { purpose of updating of the capital assets }\end{array}$ \\
\hline & $\begin{array}{l}\text { Investment privilege: reduction of taxable } \\
\text { basis by } 10 \%\end{array}$ & \\
\hline
\end{tabular}

Table 4. The concessionary Brownfield contract model within public-private partnership

\begin{tabular}{|l|c|c|}
\hline \multicolumn{1}{|c|}{ The existing tax preferences } & \multicolumn{2}{c|}{ Offered tax privileges } \\
\cline { 2 - 3 } & $\begin{array}{c}\text { General elements of the } \\
\text { tax privilege }\end{array}$ & Private elements \\
\hline $\begin{array}{l}\text { 1. VAT: the tax deduction is provided to the concessionary (gl.21 Art. } \\
\text { 174.1 of the Tax Code of the Russian Federation) }\end{array}$ & Partial or full relief from customs duties \\
\hline $\begin{array}{l}\text { 2. Income tax: it isn't considered in case of determination of a tax base } \\
\text { (the cost of depreciable property and a payment brought by the } \\
\text { concessionary to the concessor during operation of object concessionary } \\
\text { agreement) }\end{array}$ & $\begin{array}{c}\text { The income tax }-15,5 \%, \\
\text { including } \\
2 \%-\text { the federal budget, } \\
13,5 \% \text { - the regional } \\
\text { budget }\end{array}$ & $\begin{array}{c}\text { Enhancement of depreciation policy for } \\
\text { the purpose of updating of capital } \\
\text { assets }\end{array}$ \\
\hline $\begin{array}{l}\text { 3. Property tax: the parcels of land, objects of environmental } \\
\text { management and other natural resources aren't recognised the taxation } \\
\text { objects; the property belonging to military services civil defence and } \\
\text { protection law and order }\end{array}$ & $\begin{array}{c}\text { Transport tax, } \\
\text { the land tax - 0\% within } 5 \\
\text { years from the moment of of } \\
\text { registration }\end{array}$ & $\begin{array}{c}\text { Investment tax credit } \\
\text { for } 5 \text { years concerning a tax } \\
\text { is at least } 1 / 2 \text { sises of a tax and no } \\
\text { more than 3/4 refunding rates) }\end{array}$ \\
\hline & $\begin{array}{c}\text { Investment privilege: } \\
\text { reduction of taxable basis } \\
\text { by } 10 \%\end{array}$ & organisations (there \\
\hline
\end{tabular}




\section{Results}

The concessionary model of real investment process financing using the tools of financial engineering is provided in the fig. 1.

The authors offer to consider structurally this model from the positions of general and private elements of the tax incentivisation.

During the development of concessionary model of real investment process using tools of financial engineering in the conditions of upgrade and adjustment of the taxation, the standard legal acts in the field of the taxation of special economic zones, the simplified taxation system, regional regulations applied to special tax regimes were used.

The role value of private elements of the tax privilege consists in individualisation of tax preferences with designation of factorial functionality and provides a specialised assessment of parameters of implementation of concessionary activities and types of concessionary schemes.

The analysis of concessionary activities for the subjects of the Russian Federation has shown that now, there are standard and legislative procedures for free provision of the state lands for the purpose of attraction of private business in objects of state-owned property, using the principles of integration and cooperation of personnel, informational, managerial and financial resources.

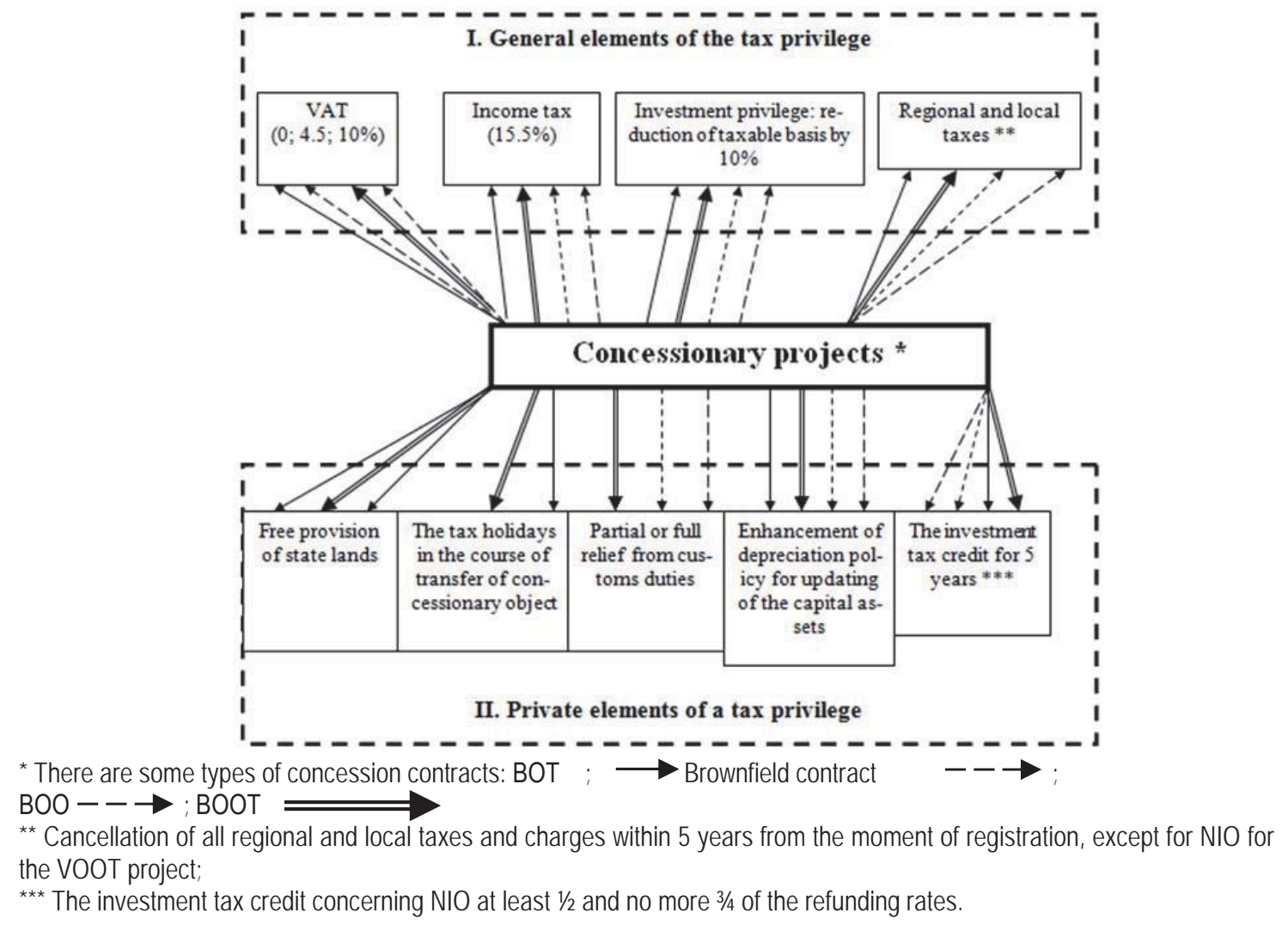

Fig. 1. Concessionary model of real investment process using financial engineering tools.

The concessions mechanism is viable and very perspective for attraction of considerable amount of real investments for development of not only transport infrastructure, but also of any industry or a segment of the Russian economic system. Thus, the significant role in application of concessions shall be assigned to regions and regional authorities where there is a large requirement and potential for implementation of infrastructure projects on the terms of concessions.

\section{Discussion}

The general system of a tax incentivisation assumes a reduction of tax rates for the purpose of increase in private 
investments into concessionary activities and effective management of state-owned property. Abroad tax privileges play an essential role. They are used as the instrument for stimulation of development of the priority economic directions. As for the offered rate of the income tax of 15.5\%, the author proves this figure with the following bases. The traditional rate of the income tax constitutes $20.0 \%$, which shares on a federal (2.0\%) and a regional component (18.0\%). Regions, according to the Russian legislation, have the right to reduce the component to $13.5 \%$. Thus, the offered rate on the income tax of $15.5 \%$ are direct incentives for investment attraction and financing of large-scale investment projects.

Regarding the indirect taxation, by the author, it is offered to use methods and methods of the VAT calculation by the principle of the taxation of special economic zones where the preferential taxation including belonging to the value added tax, is used. According to the Tax code (chapter 21), there are three rates of a tax $-0 \%, 10 \%, 18 \%$. As for the first two rates, it is offered to apply in concessionary schemes regarding construction $0 \%$, to Brownfield contract $-10 \%$. For concessions of BOT, BOOT, BOO where the management is exercised, the interest rate of the VAT, equal $4.5 \%$, i.e. a decrease by $25 \%$ of a traditional VAT rate (18\%), is offered.

The investment privilege as a direct action privilege, has an active and special-purpose character because, in case of investment gives an additional material benefit to the entity. Cancellation of this privilege has significantly lowered the profit share directed on the purposes of financing of real investments.

In a segment of a private tax incentivisation, the author offers the following preferences for effective concessionary activities and further system of financing real investments: free provision of state lands; the tax holidays in the course of transfer of concessionary object; partial or full relief from customs duties; enhancement of depreciation policy for the purpose of capital assets updating; and the investment tax credit.

The depreciation policy, for many years, remains the weakest segment of the economic policy, it does not interest the private business to update the capital assets, does not promote implementation of scientific developments and the latest technologies in production. About the unsatisfactory use of the depreciation potential, as the most effective instrument of real investments financing in respect of capital assets updating, first witnesses the availability of a tendency to increase in degree of the capital assets depreciation. Despite of the considerable volumes of investment into fixed capital, in economy a permanent growth of capital assets depreciation is observed.

The modern concept of depreciation has a number of shortcomings. An essential lack of the operating depreciation system is that it does not create a condition for updating of capital assets in the most important spheres of economic activity where degree of depreciation of a property, plant, and equipment is one of the highest. Other shortcoming is weakening of a role of depreciation as investment-financing source, because a decrease in a share of own means of the entities and organisations in structure of sources of financing of real investments is observed. The modern depreciation policy does not create incentives to implementation of scientific developments at the entities. Nowadays the downward tendency of investments into intangible assets in structure of capital investments is observed.

According to the author, to overcoming the existing shortcomings of depreciation policy, and also to increase the role of depreciation as source of financing of real investments, to create the interest to implementation and production of capital assets and technologies, it is necessary to realise a complex of actions.

The enhancement of depreciation policy for the purpose of capital assets updating and increase in amount of private investments will positively affect the subsequently modern system of real investments financing. The perspective directions of depreciation policy upgrade shall be performed by means of acceptance of management decisions by means of the generalising technique based on a choice from all set of optimum methods.

Thus, the depreciation charges at each entity include the product cost, and the amount of proceeds from sales of products is a source of financing real investments of the entity. In general, from effective depreciation policy, which is pursued in the country, productivity of economic progress in society in many respects depends.

Functioning of effective concessionary mechanisms in Russia will create serious budget consequences:

1. Inflow of investments and increase in the fiscal duties from concessionary projects.

2. Change of the public expenditures structure due to attraction of private investments, from whence, the investment expenses will be cut. Therefore, by the PPP estimates in the sector of water supply and the sewerage in the USA and Canada, it leads to cost reduction for 10-40\%, in Scotland - for 20\%, in Ireland - for $25-30 \%$. In the field of transport, by estimates of the European Commission, - for 10-17\%. According to Arthur Andersen, in Great Britain for different sectors the economy averages 17\%.

3. The entry of concessionary payment in the budget. Directly it should be noted that it not the main source of receipts in the federal budget (so, for example, in Croatia it constitutes no more than $0.5 \%$ ). The fact is that the main concessor are regional and local authorities; the purpose of concessions to find and attract the investor in the projects, which differently are not of interest, and the concessionary payments make sense only as an element of a particular tax regime. However there are also other examples - in Chile in case of the conclusion 
of one road concession the payment constituted 100 million US dollars in case of the volume of investment of 500 million.

4. Legalisation of concessionary mechanisms in Russia will demand creation and entering of chapter about a special tax regime provided by the Tax code for concessions. Legalisation of concessionary mechanisms, in fact, is already used de facto - municipal parking, private railways, even power plants, etc.

Effective financing in public-private partnerships assumes availability of a clear political will to accept some additional costs (in comparison with direct public financing). As shortcomings of concessionary activities as public-private partnership in the field of investment attraction the following acts:

- Disappearance of incentives to effective work at the investor in case of the subsidies replacing fee by consumers independent of production efficiency;

- The probability of adverse selection - complete "insurance" can lead to that investors will look for projects with excessive risk, knowing that it will be covered by the state;

- Higher probability of making inefficient decisions in government institutions than in private ones, especially in transition economies transition;

- Financial restrictions (the state has no means to participate fully in large-scale investments).

- For the purposes of the alternative budget creation, estimating the consequences of entering concessions in Russia, we will recognise that a concessionary payment balances with support mechanisms. Then the concessions:

- Will generate additional tax incomes owing to inflow of investments;

- Will cut not investment expenses of the budget in the relevant sectors of economy (redistribution of the cash flows).

- We can approach an assessment of these parameters from two sides:

- To consider and analyse a share of the world investment capital, which can appear in Russia. In this case, it should be noted that the equity going to developing countries and the countries with economies in transition, is not distributed regularly between them, and concentrates at 10-15 the countries. Especially it is characteristic for the equity which goes to infrastructure projects and which degree of concentration is even higher. If Russia manages to create a successful concessionary mode, its share will sharply increase.

- to assume that the same proportion of the BOT projects exists in other sectors as well (though it is conventional that in other sectors this share is higher), with the same growth rates of capital investments, as well as in contracts of the delegated management with investments (concessions), means approximately 5 bln. dollars per year more.

Thus, on the scales, specifics and extent of penetration into the system of the developed economic relations, the concession are comparable to privatisation processes, because the entities of industries of a social production infrastructure (housing and communal services, a public transport, thermal networks, energy stations, objects of a water utility, etc.) can become soon the concessionary object in Russia. The success of the implementation of the economic relations planner upgrade in Russia, entering the concessionary forms of government state property, will depend in many respects on completeness and quality of the legislation and economic study of all aspects of this problem.

\section{Conclusion}

In the world practice, a number of models of concessionary agreements, which proceed from the purposes and tasks of each specific project, is developed. Therefore, having analysed the successful western experience of concessions implementation in the Russian reality, it is possible to allocate a number of the major measures necessary at the current stage of implementation of concessionary activities in Russia:

- Creation of an institutional component, i.e. the specialised body responsible for implementation of a state policy in the field of concessionary activities;

- Modification of the tax code of the Russian Federation, industry regulatory legal acts, reflecting features of concessions implementation in the form of public-private partnership according to the chosen type of the concessionary agreement;

- Development and creation of mechanisms of an assessment, approval, regulation, and concessionary agreements implementation control.

The concessions mechanism is viable and very perspective for attraction of considerable amount of real investments for development of not only transport infrastructure, but also of any industry or a segment of the Russian 
economic system. Thus, the significant role in application of concessions shall be assigned to regions and regional authorities, where there is a big requirement and potential for implementation of infrastructure projects on the terms of concessions.

It should be noted that concessionary agreements as a form of state-private partnership are an instrument of interaction of the state and private business, allowing combining efforts for the solution of social and economic tasks. The need of ensuring the effective use of state-owned property, and the attraction of real investments into the Russian economy will serve as basic reasons of creation of department of concessionary agreements in structure of the Ministry of Economic Development of the Russian Federation. The matter is that the public-private partnership in the investment sphere, and in particular department of concession, shall carry out functions of the instrument of social and economic development of the state and increase of competitiveness of the Russian economy at world level. It is possible to achieve such objectives in conditions of national economy upgrade only by coordinated actions of all the potential participants; therefore, concessionary projects require a careful analysis at a stage of the management decisions making.

\section{Acknowledgments}

The authors' team expresses gratitude to Sholban Valeriievich Kara-ool, the Head of the Republic of Tyva, to the chief accountant of "UMMC Holding" JSC, Sergey Anatoliievich Degtyarev for provision of representative selection of analytical data on real investments financing within state - private partnership in the context of this scientific research.

\section{References}

Beketov, N. V. (2010). Problems and prospects of state - private partnership development: national and international experience of concessionary agreements//Financial analytics: problems and decisions, No. 9. Pages 20-25.

Hetman, L. J., Dzhonk M. D. (1997) Investment bases. - M.350 p.

Golyshev, G. A. (2014). Payment mechanism of concessionary agreements and its influence on net present value of infrastructure projects//Financial analytics: problems and decisions, No. 33. Pages 53-62.

Gribova, E. V. (2014). Concessions as one of instruments of a steady growth//Economic analysis: theory and practice, No. 10. Pages 3443.

Kabashkin, V. A., Dudetsky D. V. (2011). The analysis of specifics of public-private partnership in the conditions of globalisation processes in the world economy (on the example of the modern world oil market)//Financial analytics: problems and decisions, No. 10. Pages 2-13.

Kashbraziyev, R. V. (2013). Organisation and financing of a transport corridor "the Europe-western China": current state and problems//Finance and credit, No. 21. Pages 46-57.

Kryukova, E. M., Karpachev P. Y., Golina S. V. (2013).The priority directions of increase of investment appeal of municipal housing economy//Finance and the credit, No. 28. Pages 54-62.

Minakova, I. V., Korovina K. E. (2011). Forming of the tax regimes stimulating investing activities in the region//National interests: priorities and safety, No. 5. Pages 19-28.

Murph, J. I(2012). International market analysis: principles of the financial markets interaction. Publishing house: Alpina Publisher p.299.

Sorokina E. M., Fadeyev A. A. (2014). License agreement and agreement of commercial concession: legal and accounting aspects//International financial accounting, No. 40. Pages 10-22.

Tsyganov, D. A. (2014). Investment policy of financing of industrial enterprises//National interests: priorities and safety, No. 37. Pages 23-30.

Sharp U., Alexander G., Bailey D. (2001). Investments: The lane with English - M.: INFRA-M.

Yuzvovich, L. I. (2012). Concept and methodology of attraction of real investments: (monograph).-Yekaterinburg: Publishing house of Ural Un-ty. $316 \mathrm{p}$.

Yuzvovich, L. I., Pyatin A. N., Istomina Y. V., Yudina E. A. (2014). Features of real investment in the conditions of integration of the equity: international and Russian aspects: monograph/Yuzvovich L. I., Pyatin A. N., Istomina Y. V., Yudina E. A. M.: Publishing house of Academy of Natural Sciences. $302 \mathrm{p}$.

Zakharova, Z. A. (2014). Optimisation of conditions for attraction of private investments into infrastructure of regions//Regional economy: theory and practice, No. 22. Pages 49-57. 
ISSN 2039-2117 (online) ISSN 2039-9340 (print)
Mediterranean Journal of Social Sciences MCSER Publishing, Rome-Italy
Vol 6 No $3 \mathrm{~S} 3$ May 2015 